\title{
Article \\ Effect of Wind Loads on Collapse Performance and Seismic Loss for Steel Ordinary Moment Frames
}

\author{
Taeo Kim ${ }^{1}\left(\mathbb{D}\right.$, Sang Whan Han ${ }^{1, * \mathbb{D}}$ and Soo Ik $\mathrm{Cho}^{2}$ \\ 1 Department of Architectural Engineering, Hanyang University, Seoul 04763, Korea; tokim27@gmail.com \\ 2 Department of Civil and Environmental Engineering, University of Illinois at Urbana-Champaign, \\ Urbnan, IL 61801, USA; revenue12@naver.com \\ * Correspondence: swhan82@gmail.com; Tel.: +82-2-2220-1715
}

check for updates

Citation: Kim, T.; Han, S.W.; Cho, S.I. Effect of Wind Loads on Collapse Performance and Seismic Loss for Steel Ordinary Moment Frames. Appl. Sci. 2022, 12, 2011. https://doi.org/ 10.3390/app12042011

Academic Editor: Gianfranco De Matteis

Received: 14 January 2022

Accepted: 10 February 2022

Published: 15 February 2022

Publisher's Note: MDPI stays neutral with regard to jurisdictional claims in published maps and institutional affiliations.

Copyright: () 2022 by the authors. Licensee MDPI, Basel, Switzerland. This article is an open access article distributed under the terms and conditions of the Creative Commons Attribution (CC BY) license (https:// creativecommons.org/licenses/by/ $4.0 /)$.

\begin{abstract}
The aim of this study is to investigate the effect of wind loads on the seismic collapse performance and seismic loss for steel ordinary moment frames (OMFs). For this purpose, 9-, 12-, 15-, and 18-story steel OMFs are repeatedly designed for (1) gravity load + seismic load, (2) gravity load + seismic load + wind load (wind speed $=44 \mathrm{~m} / \mathrm{s}$ ), and (3) gravity load + seismic load + wind load (wind speed $=55 \mathrm{~m} / \mathrm{s}$ ). The seismic collapse performance and seismic loss of OMFs are evaluated using the procedures in FEMA P695 (FEMA, 2009) and FEMA P58 (FEMA, 2018), respectively. Steel OMFs designed with consideration of wind loads have larger member sections than corresponding steel OMFs designed without consideration of wind loads as expected. Although member sections are increased when wind loads are considered, the growth in the maximum base shear force and lateral stiffness of OMFs are insignificant. Unlike our expectation, OMFs designed with consideration of wind loads have higher expected annual loss $(E A L)$ than corresponding OMFs designed without consideration of wind loads.
\end{abstract}

Keywords: seismic collapse performance; steel ordinary moment frame; wind load; seismic load; seismic loss; expected annual loss

\section{Introduction}

Steel moment frames have been widely used to resist lateral forces induced by wind and seismic loads. Three types of steel moment frames are specified in ASCE 7-16 [1]: (1) ordinary moment frame (OMF), (2) intermediate moment frame (IMF), and (3) special moment frame (SMF). Specific design and detail requirements for each type of moment frame are specified in ANSI/AISC 360-16 [2], ANSI/AISC 341-16 [3], and ANSI/AISC 358-16 [4].

The most stringent design and detail requirements are required on SMFs among the three types of moment frames, whereas the least requirements are specified for OMFs [5,6]. According to ANSI/AISC 341-16 [3], connections in SMFs and IMFs should have a rotation capacity of at least 0.04 and 0.02 , respectively, whereas OMF connections should have minimal inelastic rotation capacity. The column-to-beam moment strength ratio is not specified for OMFs. Panel zones in OMFs should resist design force calculated from elastic analyses rather than maximum forces transferred from adjoining beams and columns. To compensate for the relaxed design and detail requirements on OMFs, OMFs should be designed with a larger design shear force than IMFs and SMFs.

Many studies have been conducted to assess the seismic performance of steel SMFs [7-18]. To obtain the reliable results of seismic performance assessment for steel SMFs, the cyclic behavior of SMF components has been investigated through experimental and numerical studies $[19,20]$. However, only a limited number of studies have been conducted for steel IMFs, OMFs, and existing moment frames [21-26]. According to the commentary of AISC 341-16 [3], the details of OMFs were developed based solely on the judgement of engineers rather than on the results of experimental and numerical studies. Thus, it is 
important to evaluate the seismic performance of OMFs designed according to current seismic design codes, which was the motivation of this study.

Steel OMFs are permitted only for seismic design categories (SDC) A, B, and C [1]. In such SDCs, wind loads govern design results for OMFs rather than seismic loads, particularly for high-rise buildings $[27,28]$. However, most studies on steel moment frames have focused on steel SMFs located in high-seismicity regions. In addition, wind loads have often been ignored in seismic design procedures. Thus, it is important to evaluate the seismic performance of OMFs designed according to current seismic design codes, which was the motivation of this study.

Since seismic and wind loads mainly generate lateral force and drift demands on building structures, it is important to assess the effect of wind loads on the seismic performance of the OMFs. Although larger member sections should be used for OMFs when wind loads are considered, the use of the larger member sections may not guarantee better seismic performance of the OMFs. To the best of our knowledge, no study has been conducted to investigate the effect of wind loads on the seismic performance of the OMFs. Assessment of wind load effect was another motivation of this study. The aim of this study is to evaluate the seismic performance of steel OMFs with consideration of wind load effects. The seismic performance was estimated in terms of seismic collapse performance and seismic loss.

\section{Research Methodology}

To assess the seismic performance of code-compliant steel OMFs and the effect of wind loads on the seismic performance, collapse performance was estimated according to the methodology provided in FEMA P695 [29]. In ASCE 7 [1], target seismic performance objectives are defined as seismic collapse probabilities.

For this purpose, steel OMFs with four different building heights were designed according to ASCE 7 and reference standards with and without consideration of wind loads. The seismic collapse performance of these OMFs were estimated according to FEMA P695. In addition, seismic loss estimation was conducted for these OMF buildings according to FEMA P58 [30] to investigate the effect of wind loads. The methodologies provided in FEMA P58 had been developed for performance-based earthquake seismic engineering. Figure 1 summarizes the methodology used in this study.

Design OMFs with and without Considering wind loads

Design variables: (1) building height, (2) Levels of wind load $(0,44,51 \mathrm{~m} / \mathrm{s})$

Seismic collapse performance evaluation (FEMA P695)

(1) Static pushover, (2) IDA, (3) Collapse performance

\section{Seismic loss estimation (FEMA P58)}

(1)Expected seismic loss, (2) Expected annual loss

\section{Assessment of seismic performance of OMFs and the effect of wind loads}

Figure 1. Methodology of this study.

\section{Research, Results, and Discussion}

\subsection{Design of Model Steel Ordinary Moment Frames with Consideration of the Level of Wind Loads}

In this study, to evaluate the seismic performance of steel OMFs, model office buildings with different structural heights were designed: 9-, 12-, 15-, and 18-story OMFs. Moment frames are economically effective for buildings up to 25 stories, above which their resistance is costly to control. In addition, member sections in OMFs with more than 18 stories could 
not be chosen from the section tables provided in the AISC steel construction manual [31]. Thus, this study considered OMFs with 18 or less stories.

The W-shaped sections provided in the AISC steel construction manual [31] are used for the OMFs. The plan and elevation of the 15-story model OMF buildings are shown in Figure 2. OMFs are denoted with thick solid lines, which are placed along the perimeter of the building (Figure 2a). The span length is $6.1 \mathrm{~m}$ and the height of the first story is $4.6 \mathrm{~m}$, whereas the story height for other stories is $4.0 \mathrm{~m}$. It is assumed that the column splices are located in the middle of the column for every two stories except the first story, as shown in Figure $2 b-d$. ETABS software [32] is used for the analyses and design.

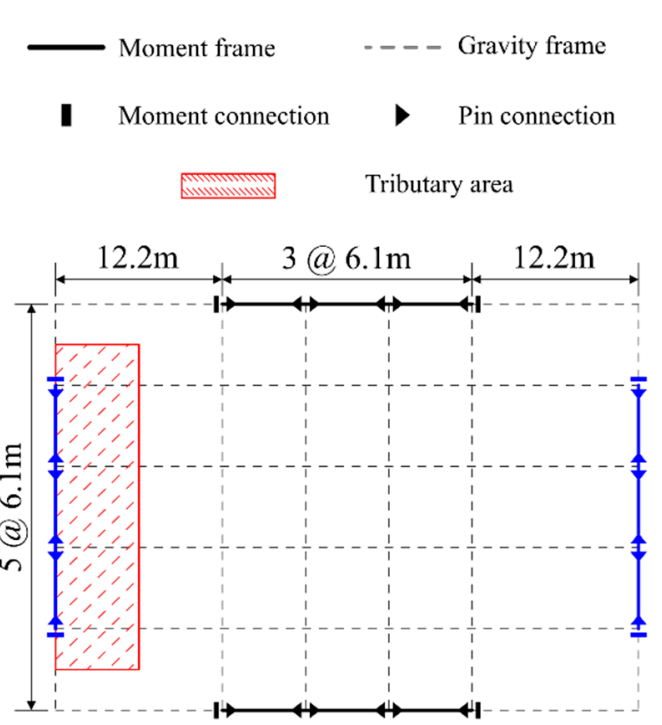

(a)

11/12F Beam: W16X40

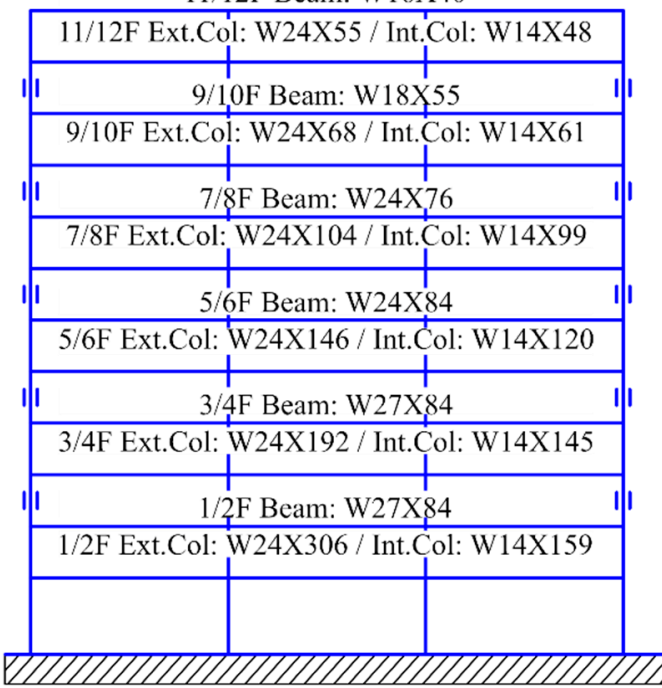

(c)

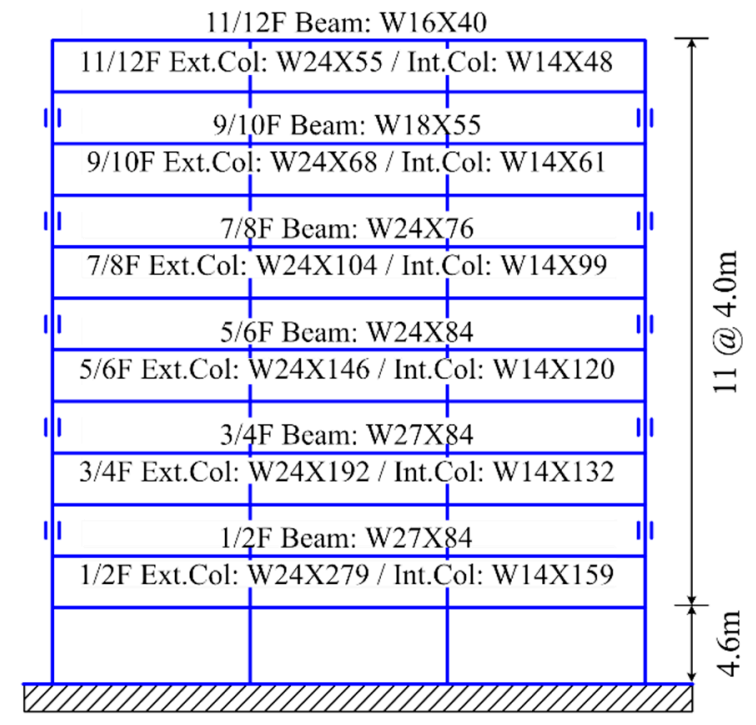

(b)

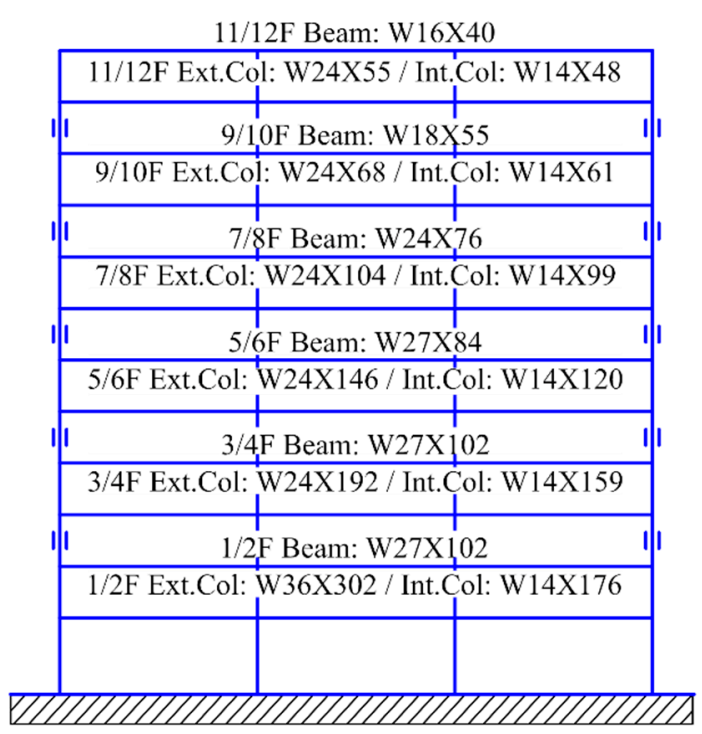

(d)

Figure 2. Plan and elevation of 15-story steel OMFs: (a) plan view; (b) elevation of 15-story W0-OMF; (c) elevation of 15-story W44-OMF; (d) elevation of 15-story W51-OMF.

The OMFs were designed according to ASCE/SEI 7-16 [1], ANSI/AISC 360-16 [2], and ANSI/AISC 341-16 [3]. The response modification coefficient $(R)$, overstrength factor $\left(\Omega_{0}\right)$, and deflection modification factor $\left(C_{d}\right)$ for the steel OMFs are 3.5, 3.0, and 3.0, respectively, according to ASCE/SEI 7-16 [1]. The risk category and importance factor $\left(I_{e}\right)$ are assumed as II and 1.0 according to ASCE 7-16 [1], respectively. Design earthquake spectral response 
acceleration parameters at short period $\left(S_{D S}\right)$ and 1-s period $\left(S_{D 1}\right)$ are defined as 0.499 and 0.199 , respectively. The seismic design category (SDC) of the buildings is classified as $C_{\max }$.

The dead, cladding, and live loads of typical office buildings are $4.31 \mathrm{kN} / \mathrm{m}^{2}, 1.20 \mathrm{kN} / \mathrm{m}^{2}$, and $2.40 \mathrm{kN} / \mathrm{m}^{2}$, respectively [12]. The steel material used in the design is ASTM A992 Gr.50 steel, which has a specified minimum yield strength $\left(F_{y}\right)$ of $345 \mathrm{MPa}$ and a specified tensile strength $\left(F_{u}\right)$ of $450 \mathrm{MPa}$. The seismic loads were determined using the equivalent lateral force (ELF) procedure.

To investigate the effect of wind loads on seismic collapse performance and seismic loss for steel OMFs, 9-, 12-, 15-, and 18-story steel OMFs are repeatedly designed for (1) gravity load + seismic load (W0-OMFs), (2) gravity load + seismic load + wind load (wind speed $=44 \mathrm{~m} / \mathrm{s}$ ) (W44-OMF), and (3) gravity load + seismic load + wind load ( wind speed $=51 \mathrm{~m} / \mathrm{s})($ W51-OMF). The basic wind speeds of $44 \mathrm{~m} / \mathrm{s}(100 \mathrm{mph})$ and $51 \mathrm{~m} / \mathrm{s}(115 \mathrm{mph})$ are the values assigned for most areas over the wind hazard map provided in Section 26.5 of ASCE/SEI 7 [1].

Wind loads were determined using basic wind speed with a mean recurrence interval (MRI) of 700 years, according to Figure 26.5-1B of ASCE 7-16. The exposure category of B was used for the OMF buildings because the model buildings were assumed to be located in urban and suburban flat areas. As seen in Figure 26.5-1B of ASCE 7-16, the basic wind speed for most areas in the USA range from $45 \mathrm{~m} / \mathrm{s}$ to $51 \mathrm{~m} / \mathrm{s}$. In this study, the upper $(=51 \mathrm{~m} / \mathrm{s})$ and lower bound values $(=44 \mathrm{~m} / \mathrm{s})$ for the range were considered to assess the effect of wind loads on the seismic performance of OMFs.

The exposure category is defined as $\mathrm{B}$, assuming that the model buildings are located in the urban or suburban flat area. Table 1 summarizes the fundamental periods $\left(T_{1}\right)$ of the model OMFs. As expected, $T_{1}$ tends to increase as the height of OMFs increases. Twelve-, fifteen-, and eighteen-story steel OMFs, designed with consideration of wind loads, have larger member sections than corresponding OMFs designed without consideration of wind loads. The increase in member sections due to wind loads is prominent in lower stories. However, for nine-story OMFs, the influence of wind loads on design results is negligible when the basic design wind speed is $44 \mathrm{~m} / \mathrm{s}$.

Table 1. Calculated fundamental period $\left(T_{1}\right)$ and upper limit of period $\left(C_{u} T_{a}\right)$ according to ASCE 7-16 of the designed steel ordinary moment frames.

\begin{tabular}{|c|c|c|c|c|c|c|c|}
\hline $\begin{array}{c}\text { Story } \\
\text { Number }\end{array}$ & W0-OMF & $\begin{array}{c}\text { Calculated } \\
\text { Period } \\
\left(T_{1}, \mathrm{~s}\right)\end{array}$ & W44-OMF & $\begin{array}{c}\text { Calculated } \\
\text { Period } \\
\left(T_{1}, s\right) \\
\end{array}$ & W51-OMF & $\begin{array}{c}\text { Calculated } \\
\text { Period } \\
\left(T_{1}, s\right) \\
\end{array}$ & $\begin{array}{l}\text { Upper Limit } \\
\text { of Period } \\
\left(C_{u} T_{a}, \mathrm{~s}\right)\end{array}$ \\
\hline 9 & 09-story W0 & 3.72 & 09-story W44 & 3.72 & 09-story W51 & 3.57 & 1.92 \\
\hline 12 & 12-story W0 & 4.44 & 12-story W44 & 4.41 & 12-story W51 & 4.20 & 2.41 \\
\hline 15 & 15-story W0 & 5.05 & 15-story W44 & 4.91 & 15-story W51 & 4.65 & 2.88 \\
\hline 18 & 18-story W0 & 5.13 & 18-story W44 & 4.84 & 18-story W51 & 4.60 & 3.32 \\
\hline
\end{tabular}

\subsection{Numerical Models of Steel Ordinary Moment Frames}

To evaluate the seismic performance of model OMFs, a numerical model is constructed using OpenSees software [33]. Figure 3 presents a nonlinear numerical model used for steel OMFs. The numerical model consists of columns, beams, and panel zones, and a leaning column installed to simulate the $P-\Delta$ effect induced by gravity loads. The leaning column is modeled as a rigid truss element and connected to the ground by a pin. The leaning column is connected to the OMF using pins (Figure 3a). The gravity axial load applied on the leaning column is calculated with effective seismic weight $(1.05 D L+0.25 L L)$ [29], where $D L$ and $L L$ are the superimposed dead and live loads, respectively. The damping matrix is constructed using the commonly used Rayleigh damping matrix based on a damping ratio of $2 \%$ for the first and fifth modes [34-36]. It is noted that in NIST GCR 17-917-46v1 [34] and ATC 72-1 [35], it is recommended that the first-mode period and the third or higher 
period should be used to construct the Rayleigh damping matrix. In this study, the first and fifth modes were used. In order to avoid unrealistic damping forces, stiffness- and mass-proportional damping terms are constructed only using the elastic line elements for beams and columns, and nodes for lumped mass [36].

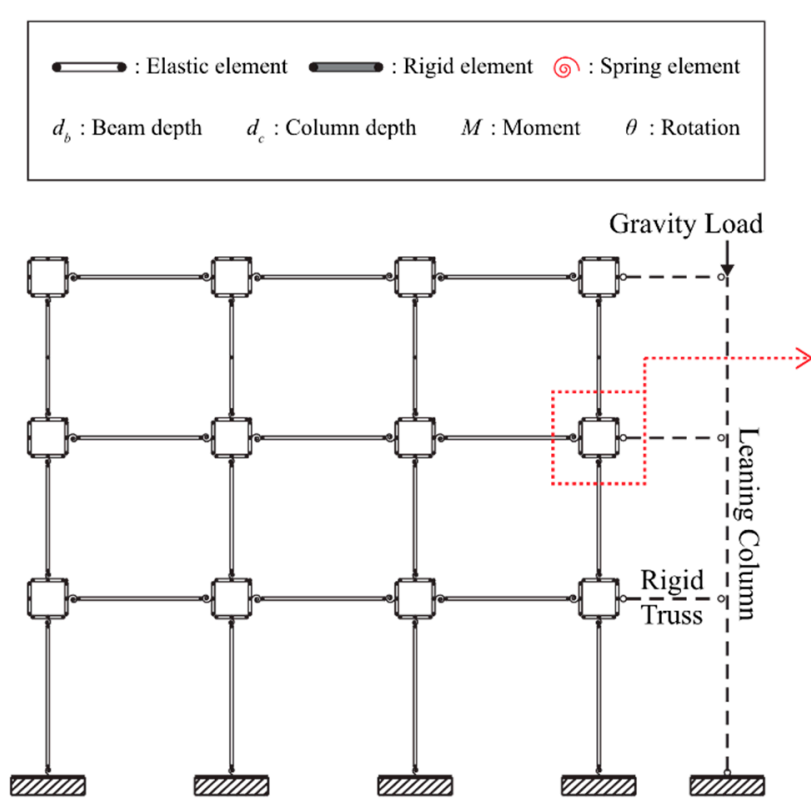

(a)

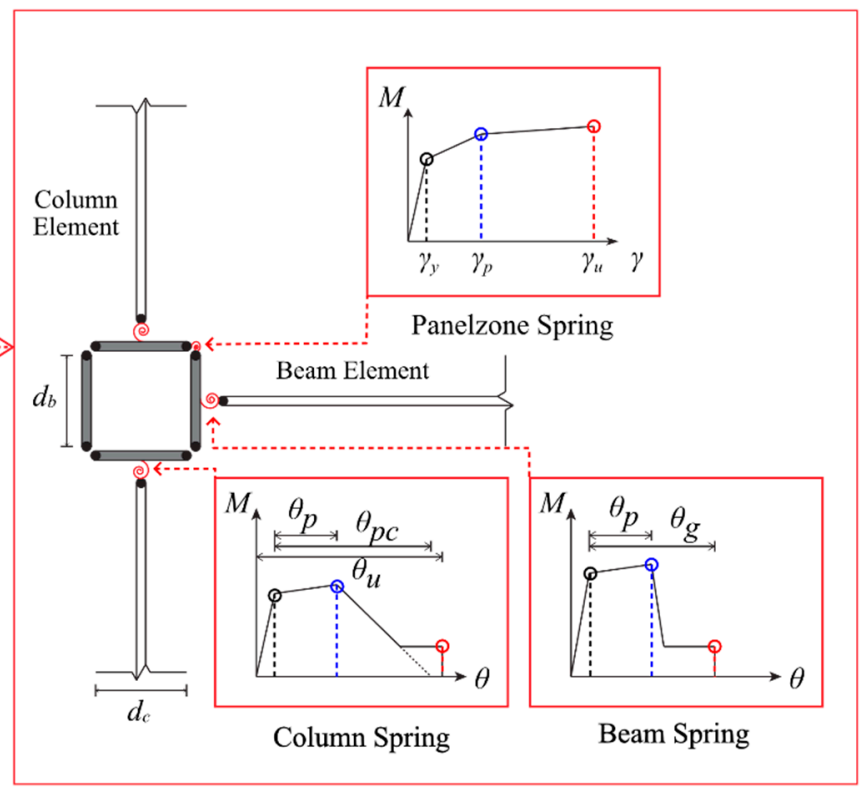

(b)

Figure 3. Numerical model for model structure: (a) Model configuration of steel OMF; (b) detail of the beam-to-column connection model.

Individual beam and column elements are modeled using an elastic line element with rotational plastic hinge elements placed at both ends of the elastic element. The moment capacity of the column section should be reduced due to stress generated by axial force. The modeling parameters of the concentrated plastic hinges for steel columns are determined according to Lignos et al. [37].

The welded unreinforced flange-bolded web (WUF-B) connection is used for OMFs in this study, which is modeled as shown in Figure 3b. A panel-zone consists of four rigid line elements and one rotational spring element simulating the trilinear behavior of the panel zone [38]. To simulate the cyclic behavior of the WUF-B connection, the modified IMK model [39] is used. As shown in Figure $3 b, \theta_{p}$ is the drift ratio $(\theta)$ at capping strength, $\theta_{g}$ is the $\theta$ value at fracture, $M_{c}$ is the capping moment strength, and $M_{y}$ is the effective yield strength. The $M_{c}$ and $M_{y}$ values for beams are estimated according to Lignos and Krawinkler [19], and the $\theta_{p}$ and $\theta_{g}$ values are estimated according to ASCE 41 [40]. The residual strength is defined as $20 \%$ of the plastic moment strength for WUF-B connections according to Stojadinovic et al. [41] and Han et al. [42]. The accuracy of the connection model was verified by Han et al. [43]. In Figure 3b, empty circles with black, blue, and red colors denote yielding, capping, and fracture, respectively. Panel zones are modeled according to Gupta and Krawinkler [38]. Composite actions [11,44-46] due to slab effects are not considered in this study because of insufficient test data to verify the numerical models.

\subsection{Seismic Collapse Performance of Steel Ordinary Moment Frames}

Nonlinear static analyses (pushover) are performed using lateral forces with a vertical distribution following the fundamental mode shape of a frame according to FEMA P695 [29] methodology. Figure 4 shows the pushover curves of OMFs, from which overstrength factor $(\Omega)$ and period-based ductility $\left(\mu_{T}\right)$ are determined using the following equations:

$$
\Omega=V_{\max } / V_{\text {design }}
$$




$$
\begin{gathered}
\mu_{T}=\delta_{u} / \delta_{y, e f f} \\
\delta_{y, e f f}=C_{0} \frac{V_{\max }}{W}\left[\frac{g}{4 \pi^{2}}\right]\left(\max \left(T, T_{1}\right)\right)^{2}
\end{gathered}
$$

where $V_{\max }$ is the maximum base shear, $V_{\text {design }}$ is the design base shear force, $\delta_{y, e f f}$ is the effective yield roof displacement, and $\delta_{u}$ is the maximum roof displacement measured when the strength decreases to $0.8 V_{\max }$.
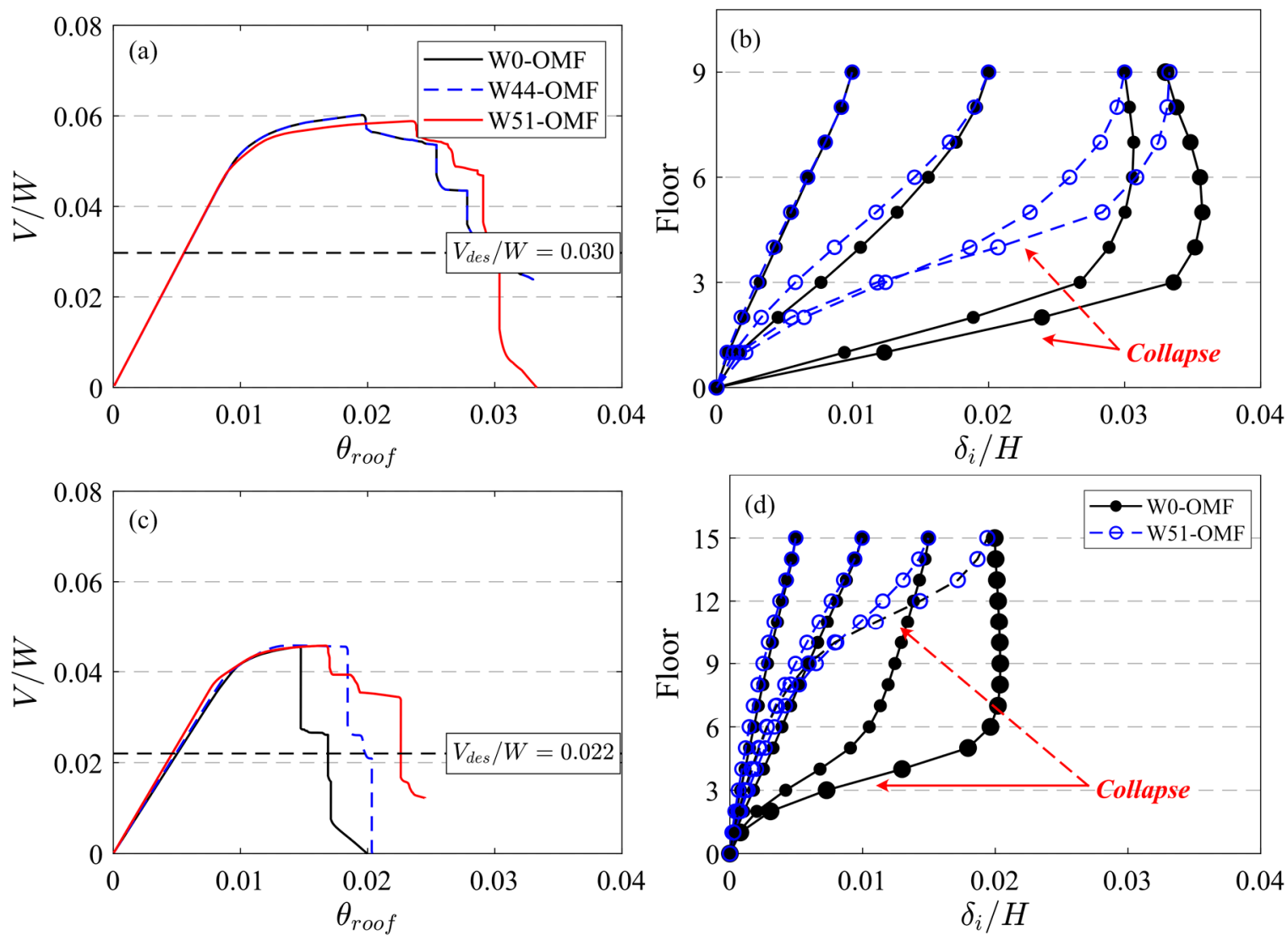

Figure 4. Result of pushover analysis for 9- and 15-story steel OMFs: (a,c) Pushover curves; (b,d) normalized floor displacement $\left(\delta_{i} / H\right)$ of W0- and W51-OMFs at specific normalized roof displacements until collapse stage.

Figure 4a,c shows the pushover curves of 9-story and 15-story OMFs. The cyclic curves of OMFs does not vary significantly according to the application of wind loads. The maximum strength and lateral stiffness of W44- and W51-OMFs are similar with those of corresponding W0-OMFs. Figures $3 \mathrm{~d}$ and $4 \mathrm{~b}$ show floor displacement normalized by building height $\left(\delta_{i} / H\right)$. As mentioned in the previous section, the consideration of wind load in design leads to an increase in member sections, especially for lower stories. Since in upper stories, member sections do not increase unlike in the lower stories, significant damage could occur in the upper stories during earthquakes. This phenomenon is more prominent when OMFs approach collapse state (see Figure $4 b, d$ ).

Figure 5 shows the values of $\Omega$ and $\mu_{T}$ for individual OMFs. As shown in this figure, the $\Omega$ value of OMFs does not vary according to structural height and level of wind loads. All steel OMFs have $\Omega$ values of about 2.0, which is less than the value of system overstrength factor $\left(\Omega_{0}=3.0\right)$ specified for steel OMF in ASCE 7 [1]. The $\mu_{T}$ value of OMFs tends to decrease gradually with increasing building height. It is also observed that $\mu_{T}$ increases with an increase in the level of wind loads. 

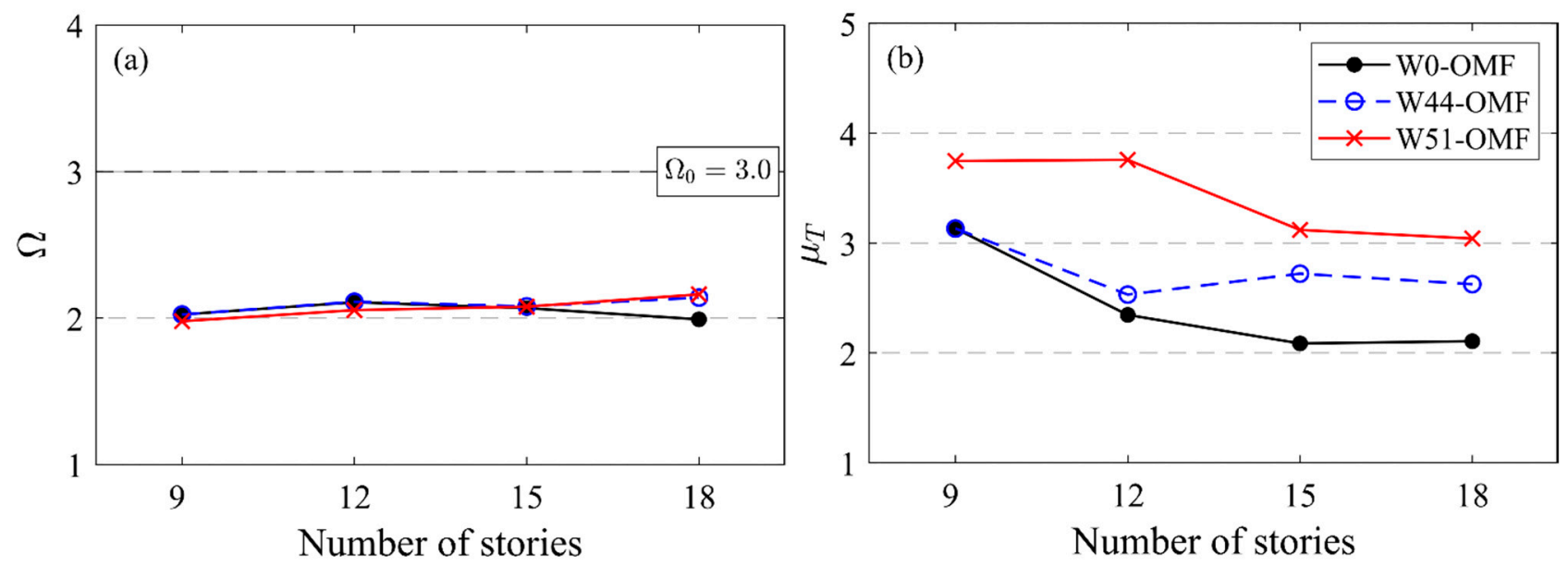

Figure 5. Overstrength factor $(\Omega)$ and period-based ductility $\left(\mu_{T}\right)$ of steel OMFs obtained from pushover analyses, (a) The $\Omega$ values, (b) The $\mu_{T}$ values.

Figure 6 shows the distribution of damage in the 15-story OMFs designed without and with wind loads ( $44 \mathrm{~m} / \mathrm{s}$ and $51 \mathrm{~m} / \mathrm{s}$ ) near collapse. As shown in this figure, damage is concentrated in upper stories for the W44- and W51-OMFs, whereas for the W0-OMF, damage is more widely distributed in the lower stories than that for the W44-, and W51OMFs. This could be the reason that the maximum shear force of W0-OMF is similar to those of the corresponding W44-, and W51-OMFs (Figure 4a,c), although the member sections for the W0-OMF are less than those of the W44-, and W51-OMFs.

$0 \quad$ Yielding strength

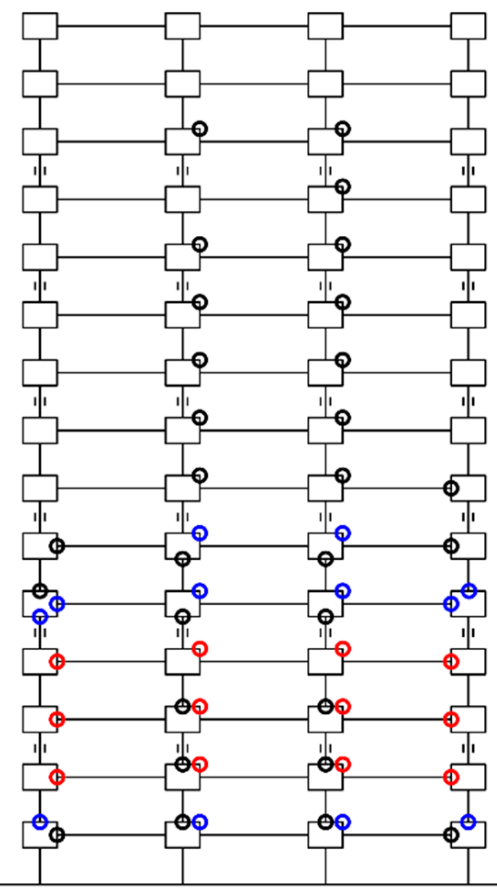

(a)
- Capping strength

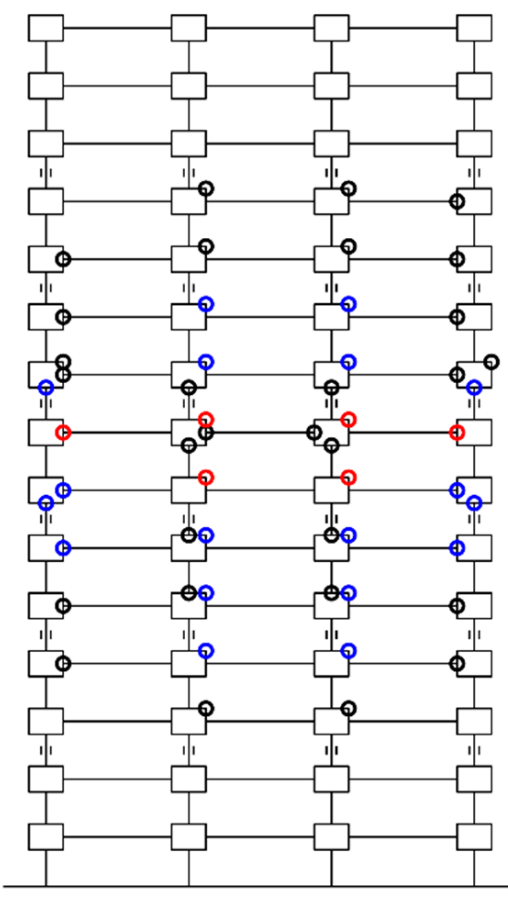

(b)
O Fracture

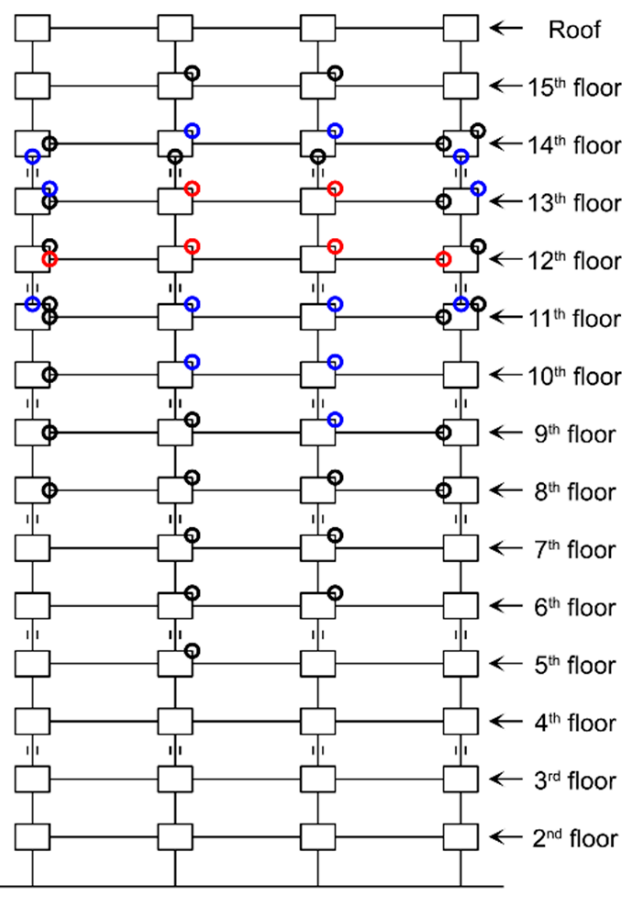

(c)

Figure 6. Plastic hinge distribution in pushover analysis for 15-story OMFs near collapse: (a) The 15-story W0-OMF; (b) 15-story W44-OMF; (c) 15-story W51-OMF.

All 15-story OMFs (W0-, W44-, and W51-OMFs) experience yielding and fracture mainly in exterior beams and interior panel zones. The fracture in the interior panel zones can be attributed to the fact that OMF panel zones are designed for the force demand from 
the load combinations specified in ASCE 7 [1] instead of that developed from the plastic moments of nearby beams. The locations of the most significant damage in the 15-story W0, W44- and W51-OMFs are the fourth, ninth, and twelve stories, respectively, which are the same stories that experience the largest story drift (Figure $4 \mathrm{~b}, \mathrm{~d}$ ). It is noted that in all the OMFs in Figure 6, plastic hinges are not developed at the bottom of the first story columns. This indicates that steel OMFs, according to the current design procedure, may not have the maximum base shear capacity intended in seismic design standards. This is attributed to the fact that the $\Omega$ values of all OMFs are smaller than overstrength factor $\left(\Omega_{0}=3.0\right)$ specified for OMFs in ASCE 7 [1] (Figure 5a). For other OMFs with different numbers of stories, similar observations are obtained.

An incremental dynamic analysis (IDA [42]) was also performed for the steel OMFs, from which collapse intensity and fragility curves were obtained. The fragility curve of the model frame was constructed according to the FEMA P695 [29] methodology. An ensemble of 44 far-field ground motions provided by FEMA P695 are used to perform the IDA. The hunt and fill algorithm [47] is used to efficiently conduct the IDA. Due to the limitations of the page, IDA curves for individual ground motions of all frames are not included, and the median IDA curves of each steel OMF are presented in Figure 7. Table 2 summarizes the parameter values obtained from the pushover analysis and the IDA. The collapse intensity $\left(S_{C T}\right)$ of a structure is defined as a 5\%-damped pseudo spectral acceleration $P S A\left(T_{1}, 5 \%\right)$ at $T_{1}$, which leads to the global dynamic instability (GI) of a structure. When a structure reaches the GI state, the lateral displacement of the structure increases without bound by a slight increase in ground motion intensity.
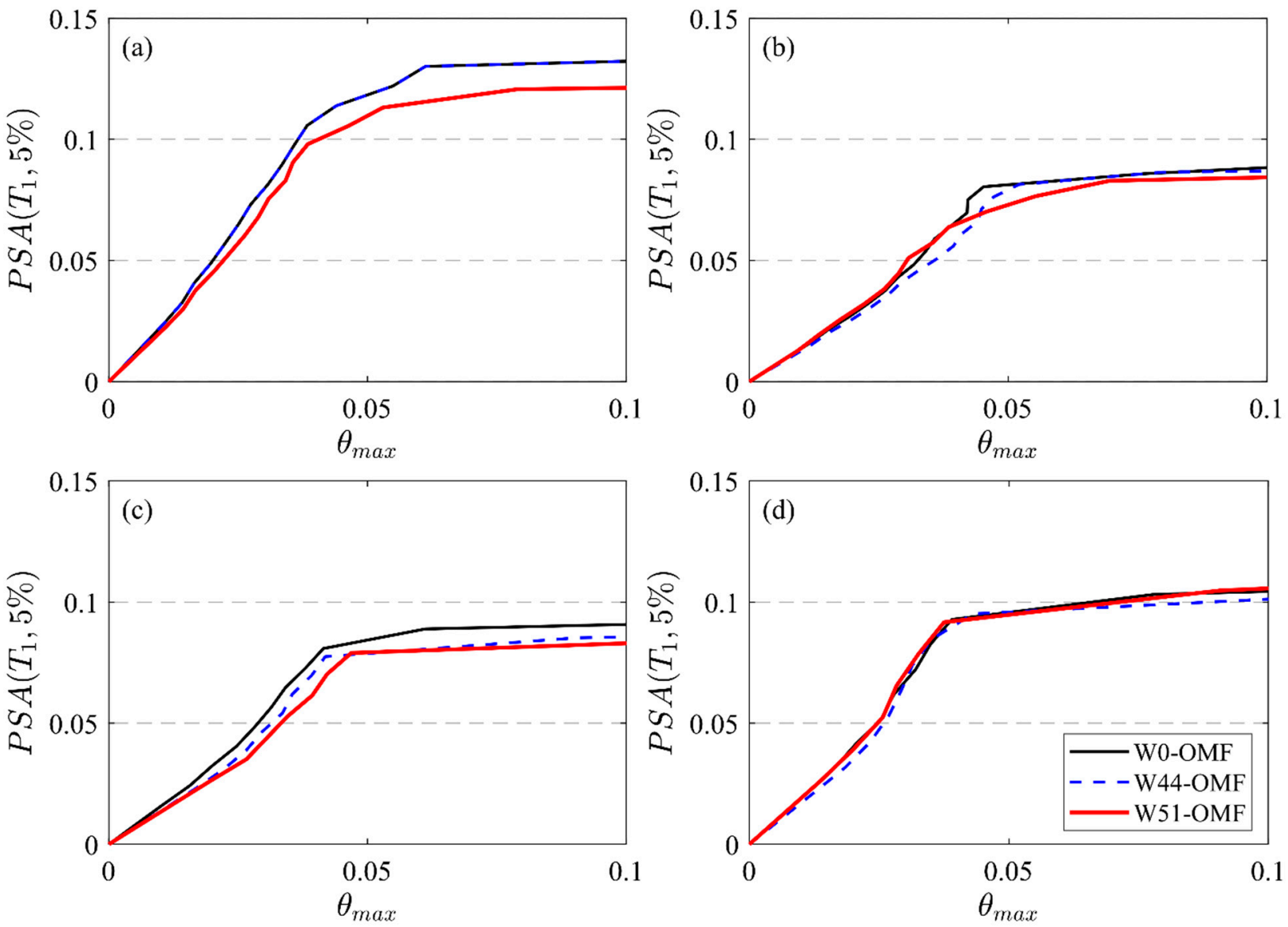

Figure 7. Median IDA curves for OMFs: (a) 9-story; (b) 12-story; (c) 15-story; (d) 18-story. 
Table 2. Parameters from pushover and IDA results.

\begin{tabular}{|c|c|c|c|c|c|c|c|c|}
\hline $\begin{array}{l}\text { Design } \\
\text { Type }\end{array}$ & $\begin{array}{c}\text { Number of } \\
\text { Stories }\end{array}$ & $\begin{array}{c}\text { Structural } \\
\text { Height (m) }\end{array}$ & $V_{d e s} / W$ & $V_{\max } / W$ & $\Omega$ & $\mu_{T}$ & $\beta_{R T R}$ & $\hat{S}_{C T}(\mathrm{~g})$ \\
\hline \multirow{4}{*}{ W0-OMFs } & 9 & 36.3 & 0.030 & 0.060 & 2.02 & 3.13 & 0.406 & 0.132 \\
\hline & 12 & 48.2 & 0.024 & 0.050 & 2.11 & 2.35 & 0.445 & 0.088 \\
\hline & 15 & 60.0 & 0.022 & 0.045 & 2.07 & 2.09 & 0.461 & 0.091 \\
\hline & 18 & 71.9 & 0.022 & 0.044 & 1.99 & 2.11 & 0.484 & 0.104 \\
\hline \multirow{4}{*}{ W44-OMFs } & 9 & 36.3 & 0.030 & 0.060 & 2.02 & 3.13 & 0.406 & 0.132 \\
\hline & 12 & 48.2 & 0.024 & 0.050 & 2.11 & 2.53 & 0.459 & 0.087 \\
\hline & 15 & 60.0 & 0.022 & 0.046 & 2.08 & 2.72 & 0.481 & 0.086 \\
\hline & 18 & 71.9 & 0.022 & 0.047 & 2.14 & 2.63 & 0.484 & 0.101 \\
\hline \multirow{4}{*}{ W51-OMFs } & 9 & 36.3 & 0.030 & 0.059 & 1.98 & 3.75 & 0.416 & 0.121 \\
\hline & 12 & 48.2 & 0.024 & 0.049 & 2.05 & 3.76 & 0.478 & 0.084 \\
\hline & 15 & 60.0 & 0.022 & 0.046 & 2.08 & 3.12 & 0.497 & 0.083 \\
\hline & 18 & 71.9 & 0.022 & 0.048 & 2.16 & 3.04 & 0.571 & 0.106 \\
\hline
\end{tabular}

The median collapse intensity $\left(\hat{S}_{C T}\right)$ of W0-OMFs is generally similar with that of corresponding W44- and W51-OMFs, where $\hat{S}_{C T}$ is the median value of $S_{C T}$ for 44 ground motions (Figure 7). This indicates that the consideration of wind loads in design may not affect the seismic collapse intensity of OMFs. However, the record-to-record dispersion $\left(\beta_{R T R}\right)$ of W44- and W51-OMFs is larger than that of W0-OMF. With increasing $\beta_{R T R}$, the collapse probability of a structure increases. This indicates that the collapse probability of W44- and W51-OMFs is higher than that of corresponding W0-OMF.

According to Eads et al. [48], an increase in $\beta_{R T R}$ leads to an increase in the collapse probability for low-intensity ground motions, and the effect of $\beta_{R T R}$ on life-cycle collapse probability is significant. Additionally, with a decrease in $T_{1}$, ground motion intensity demands at a given hazard level increases. The $T_{1}$ values of OMFs designed with consideration of wind loads are shorter than those of corresponding OMFs designed without consideration of wind loads. Thus, the collapse performance of W44- and W51-OMFs could be less satisfactory than that of corresponding W0-OMF due to higher seismic intensity demands, similar seismic collapse intensity (capacity), and larger $\beta_{R T R}$. Thus, an increase in member sections only in the lower stories of the structure due to the consideration of wind loads may adversely affect the seismic performance of OMFs. This indicates that when evaluating the seismic performance of OMFs, the effect of wind loads should be considered in the evaluation.

In addition, this study inspects the distribution of elastic story drift ratios along the building height for 44 far-field ground motion sets [29]. The story drift ratio $\left(S D R_{i}\right)$ is calculated as the story drift of the $i$ th story divided by story height. Figure 8 shows the distribution of story drift ratios for 15-story W0- and W51-OMFs. A solid gray circle in the figure represents story drift ratios generated by individual ground motions. Median $S D R_{i}$ values for W0- and W51-OMFs are included in this figure.

For the 15-story steel OMFs, the larger elastic $S D R_{i}$ values are obtained in the upper stories of the structure. This is because the effect of higher modes. As seen in the previous section, the W51-OMF has larger $S D R_{i}$ in the upper stories than W0-OMF because of the increase in member sections in the lower stories when wind loads are taken into consideration. The dispersion of $S D R_{i}$ in the upper stories for the W51-OMF is larger than that for the W0-OMF. The larger dispersion of $S D R_{i}$ in the upper stories for the W51OMF may be attributed to the effect of larger lateral drifts in the upper stories and more significant contributions of higher modes. 

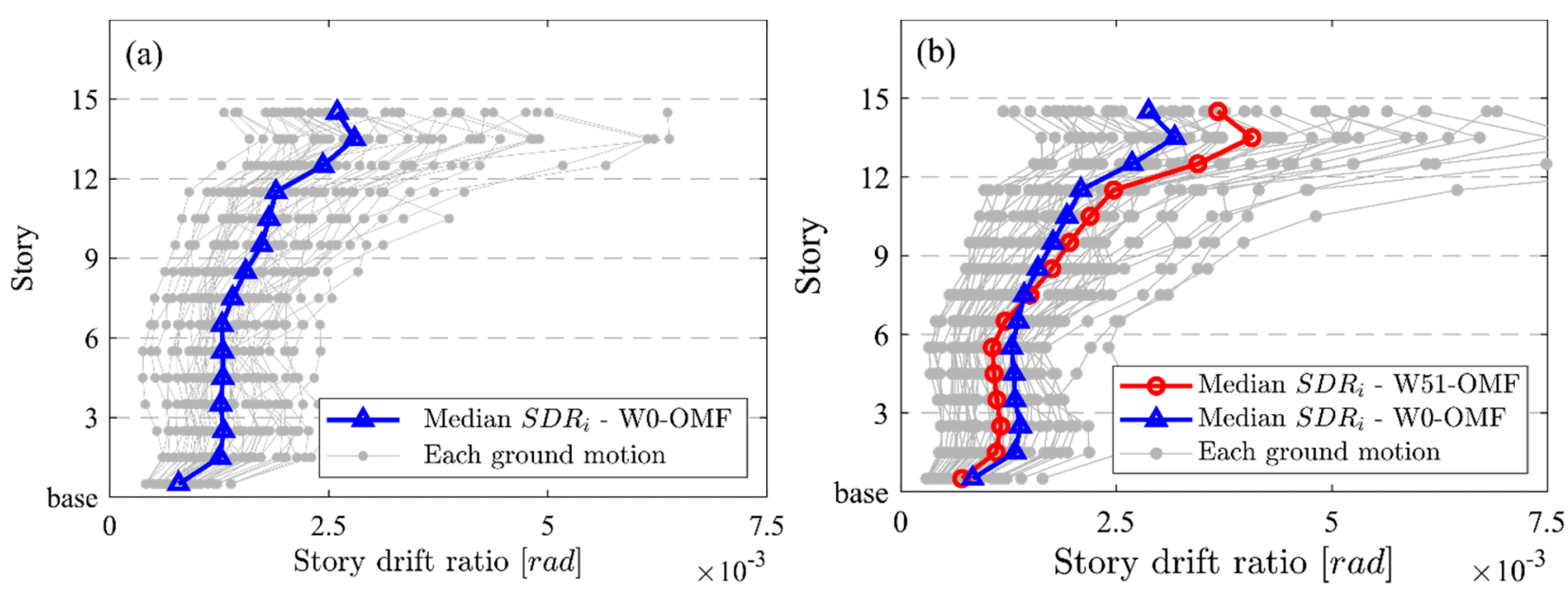

Figure 8. Story drift ratio $\left(S D R_{i}\right)$ in the elastic response range: (a) 15—story W0-OMF; (b) 15—story W51-OMF.

\subsection{Seismic Loss of Steel Ordinary Moment Frames}

In this study, the effect of wind loads on the seismic performance of steel OMFs was investigated. To achieve the research objective, the seismic loss estimation was conducted according to FEMA P58 [30]. In seismic loss estimation, the various levels of damage states for structural and nonstructural elements should be considered. As noted that in previous sections, collapse limit state is only considered to evaluate the seismic performance of OMFs, which may overestimate the seismic performance [49].

Three limit states are considered to evaluate the seismic loss: (1) the limit state, in which damage to structural and nonstructural components occurs and results in repair costs (Repair); (2) the limit state in which collapse does not occur but requires demolition and reconstruction due to severe damage (Demolition); and (3) the limit state in which collapse occurs due to earthquake (Collapse). Considering each limit state, the total expected seismic loss for a specific ground motion intensity measure (im) in the building $\left(E\left(L_{T} \mid \mathrm{im}\right)\right)$ can be evaluated based on the following equation proposed by Ramirez and Miranda [50]:

$$
\begin{gathered}
E\left(L_{T} \mid i m\right)=E\left(L_{R} \mid R, i m\right) P(R \mid i m) P(N C \mid i m)+ \\
E\left(L_{D} \mid D, i m\right) P(D \mid i m) P(N C \mid i m)+E\left(L_{C} \mid C, i m\right) P(C \mid i m),
\end{gathered}
$$

where $E\left(L_{R} \mid R, i m\right), E\left(L_{D} \mid D, i m\right)$, and $E\left(L_{C} \mid C, i m\right)$ are the expected seismic loss associated with repair, demolition, and collapse limit state at specific $i m$, respectively. In this equation, $P(C \mid i m)$ is the probability that collapse occurs at a given im; $P(N C \mid i m)$ is the non-collapse probability $[1-P(C \mid i m)]$; and $P(D \mid i m)$ is the probability of occurrence of the demolition limit state, which is defined using residual inter-story drift ratio (RIDR) [50]. The seismic loss required to repair structural and nonstructural component damage caused by a ground motion was calculated according to FEMA P58 [30]. A reconstruction procedure is required to restore the structure experiencing collapse. For the demolition limit state, costs are required for the demolition of the building, the removal of debris, and the reconstruction to restore the performance of the building. In this study, the seismic loss associated with demolition limit state is assumed to be equivalent to $125 \%$ of the total replacement cost [30]. Therefore, the expected seismic losses associated with demolition and collapse limit states are assigned as $125 \%$ and $100 \%$ of the total replacement cost, respectively.

Individual damage states and repair costs for structural and nonstructural components are defined according to FEMA P58 Vol 3 [51]: supporting electronic materials and background documentation [51]. The total replacement cost of the model buildings was assumed to be 2691 USD per square meter [52]. The quantities and types of structural components considered in this study are briefly summarized in Table 3, and the quantities 
and types of nonstructural components are defined using normative quantity estimation tool provided by FEMA P58 [51].

Table 3. The types and quantity per story for structural components of the model building.

\begin{tabular}{cccc}
\hline Component Name & Unit & Quantity Per Story & EDP \\
\hline Column base plate & EA & 36 (only first story) & $S D R$ \\
\hline Column splice & EA & $\begin{array}{c}36 \text { (at the story where the } \\
\text { column splice is located) }\end{array}$ & $S D R$ \\
\hline Column & EA & 36 & $S D R$ \\
\hline $\begin{array}{c}\text { Post-Northridge } \\
\text { WUF-B connection }\end{array}$ & EA & 16 & $S D R$ \\
\hline Shear tab connection & EA & 96 & $S D R$ \\
\hline
\end{tabular}

The expected annual loss $(E A L)$ can be calculated using $E\left(L_{T} \mid i m\right)$ (Equation (4)) and the seismic hazard curves representing the frequency of occurrence of a specific im $\left(\lambda_{i m}\right)$. To construct the seismic hazard curve, the OMFs are assumed to be located at $2393 \mathrm{E}$ Tropicana Ave. in Las Vegas, NV $\left(36.099^{\circ} \mathrm{N},-115.119^{\circ} \mathrm{W}\right)$, which used a similar design spectral acceleration as in the seismic design for OMFs. The hazard curve is obtained from the USGS unified hazard tool (https: / / earthquake.usgs.gov/hazards/interactive/, accessed on 15 February 2022). The $E A L$ value is calculated using Equation (5) as follows:

$$
E A L=\sum_{i m} E\left(L_{T} \mid i m\right)\left|\frac{\Delta\left(\lambda_{i m}\right)}{\Delta(i m)}\right| \Delta(i m),
$$

where $\left|\frac{\Delta\left(\lambda_{\text {im }}\right)}{\Delta(i m)}\right|$ is the absolute value of the slope of the seismic hazard curve.

In this study, nonlinear response analyses were performed for OMF buildings using 44 far-field ground motions scaled to multiple hazard levels [29]. Figure 9 shows the median peak story drift ratio (SDR) of 15-story OMFs designed with and without consideration of wind loads for three different hazard levels. The distribution of SDR for other OMFs is plotted in Appendix A (Figure A1).

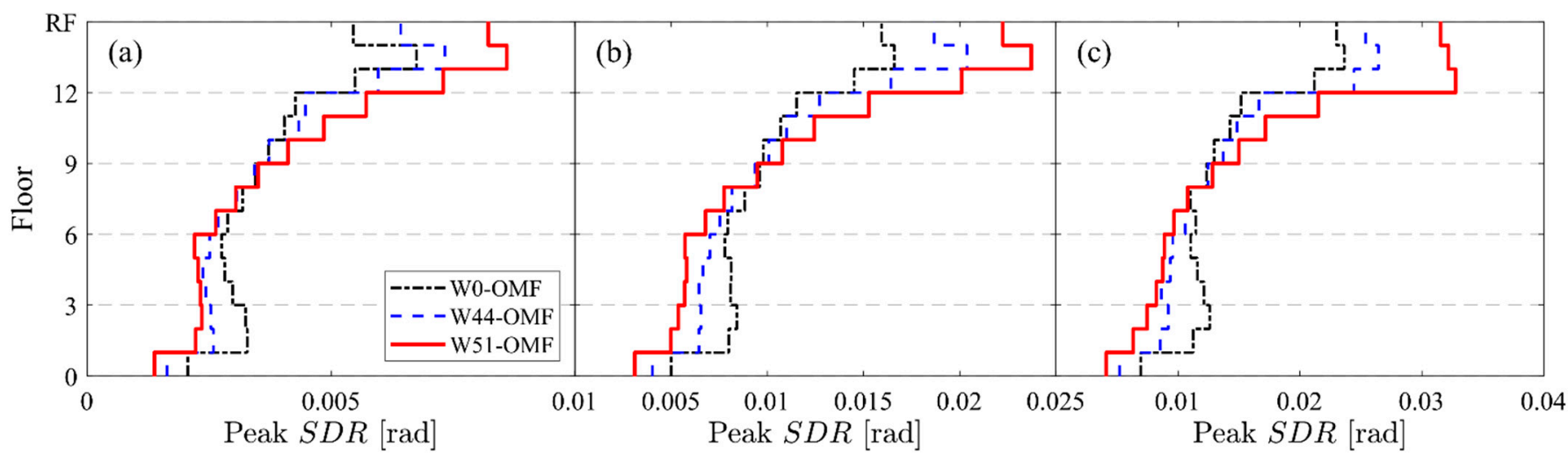

Figure 9. Peak story drift ratio $(S D R)$ of 15-story steel OMFs: (a) service level earthquake (SLE); (b) design-based earthquake (DBE); (c) maximum considered earthquake (MCE).

As shown in Figure 9, the larger SDR occurs in the upper stories than in the lower stories irrespective of different seismic hazard levels, which is due to the contributions of higher modes. A similar observation is made in elastic range (Figure 8).

The distribution of $S D R$ along the building height affects the damage in the driftcontrolled nonstructural and structural components. For OMFs designed with consideration of wind loads, the concentration of higher SDR in the upper stories becomes more 
significant than that for the OMF designed without consideration of wind loads. This phenomenon is more apparent when a larger wind load $(51 \mathrm{~m} / \mathrm{s})$ is used in the design. The W44-OMF has $8.6 \%, 22.8 \%$, and $11.9 \%$ larger $S D R_{\max }$ than the W0-OMF for the SLE, DBE, and MCE hazard levels, respectively, where $S D R_{\max }$ is the maximum value among the $S D R$ s of individual stories. The increase in $S D R_{\max }$ is more prominent for the W51-OMF, which has $27.4 \%, 42.9 \%$, and $38.6 \%$ larger $S D R_{\text {max }}$ than the W0-OMF for the SLE, DBE, and MCE hazard levels, respectively. This indicates that the increase in member sections in the lower stories of OMFs due to the consideration of the wind loads may adversely affect not only the collapse risk but also the drift-controlled nonstructural and structural components. A similar observation is made for OMFs with different numbers of stories (Figure A1).

Figures 10 and 11 show repair costs associated with the structural, displacement-based, and acceleration-based nonstructural components in the individual stories for the 15-story OMFs at SLE and DBE hazard levels. The median repair costs normalized by the replacement cost for SLE and DBE hazard levels are only plotted in Figures 10 and 11, where STR, NSTR-D, and NSTR-A represent mean repair cost associated with structural component, drift-controlled nonstructural component, and acceleration-controlled nonstructural component, respectively.

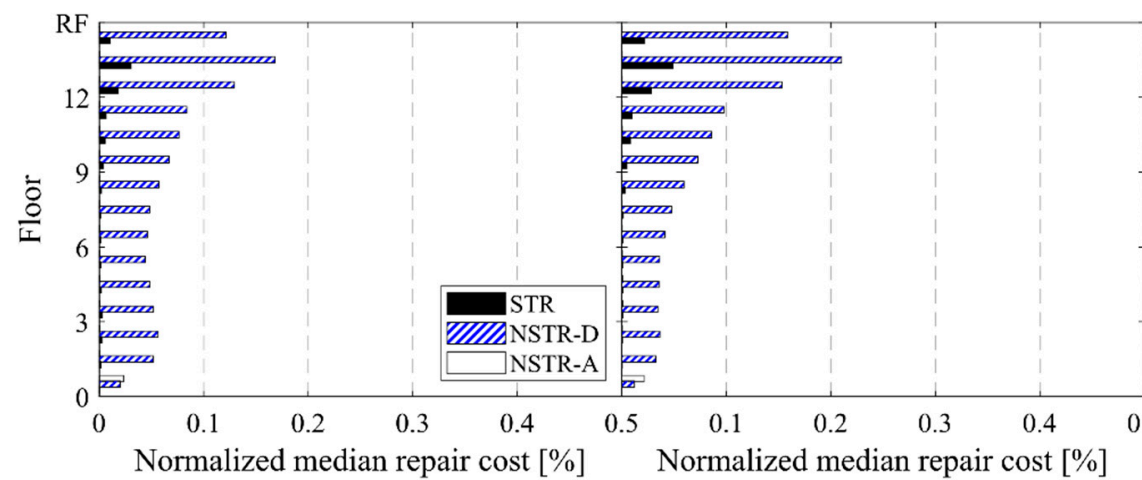

(a) (b)

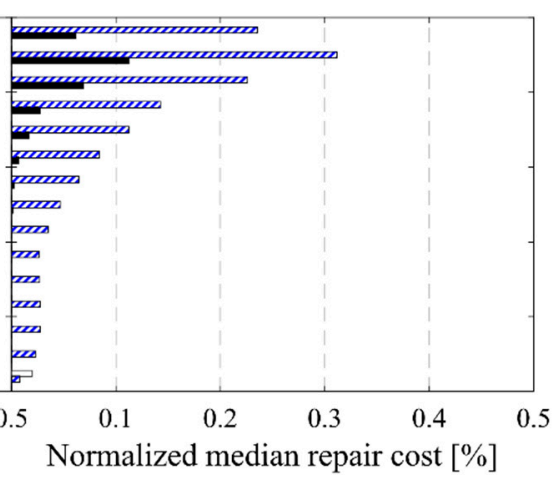

(c)

Figure 10. Normalized median repair cost of 15-story steel OMFs at SLE hazard level: (a) W0-OMF; (b) W44-OMF; (c) W51-OMF.

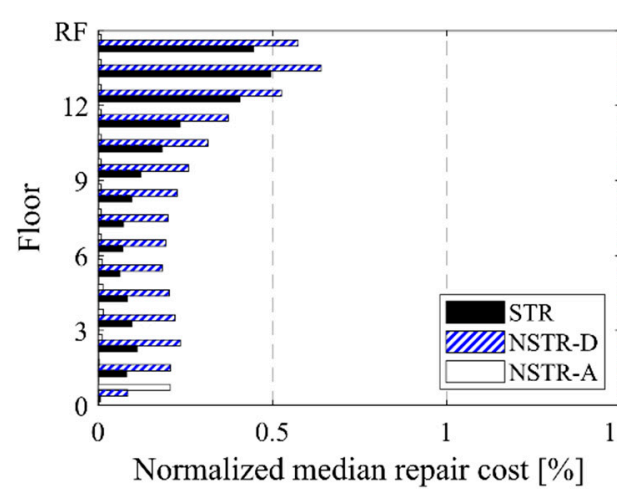

(a)

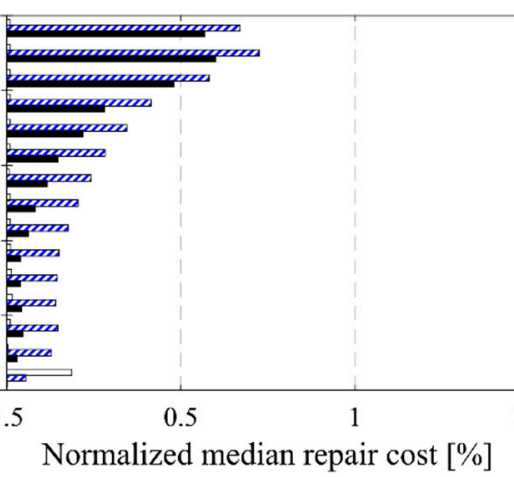

(b)

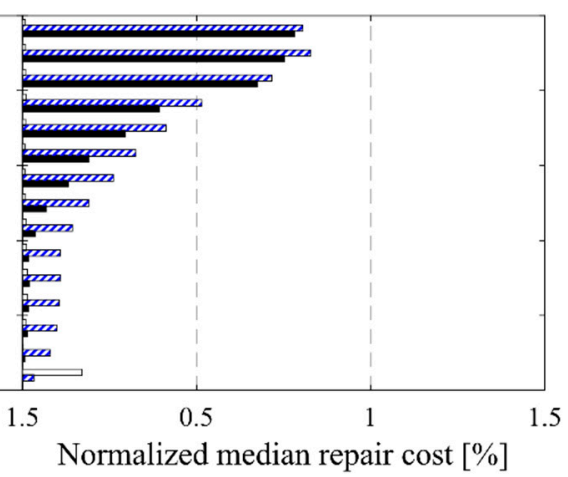

(c)

Figure 11. Normalized median repair cost of 15-story steel OMFs at DBE hazard level: (a) W0-OMF; (b) W44-OMF; (c) W51-OMF.

As shown in Figure 10, for the repair cost induced by ground motions for the SLE hazard level, the contribution of NSTR-D is dominant. The W44- and W51-OMFs have $18 \%$ and $75 \%$ larger expected repair costs for the SLE hazard level than the W0-OMF. Due to damage concentration in the upper stories for the W44-OMF and W51-OMF, the repair costs associated with SDR sharply increases. As mentioned earlier, this phenomenon is attributed to the increase in member sections in the lower stories for these OMFs due to 
wind loads. However, the repair costs for the lower stories are higher for the W0-OMF than for the W44-OMF and W51-OMF.

Figure 11 shows the repair costs for the DBE hazard level. As shown in the figure, the repair costs associated with the NSTR-D is also dominant, as observed for the SLE hazard level. More repair costs for DBE hazard level are required than those for the SLE hazard level. For the DBE hazard level, the W44- and W51-OMFs have $12 \%$ and 39\% larger repair costs than the W0-OMF, respectively. The contribution of STR on the repair costs for the DBE hazard level becomes more significant than that for the SLE hazard level. It is noted that NSTR-A did not have a significant effect on the repair costs associated with STR and NSTR-D. This is because the peak floor acceleration (PFA) is small in the steel OMFs designed for the SDC level of $C_{\max }$ or lower.

To evaluate seismic loss for all limit states according to $i m$, normalized expected seismic loss is plotted in Figure 12, where the horizontal and vertical axes represent the spectral acceleration normalized to the spectral acceleration corresponding to the maximum considered earthquake $\left(S_{M T}\right)$ and the expected seismic loss $(E L)$ normalized to the total replacement cost, respectively. Figure 13 shows the contribution of each limit state (repair, demolition, and collapse limit states) on EL. This figure shows the contributions of each limit state on the expected seismic loss according to $\mathrm{im}$.

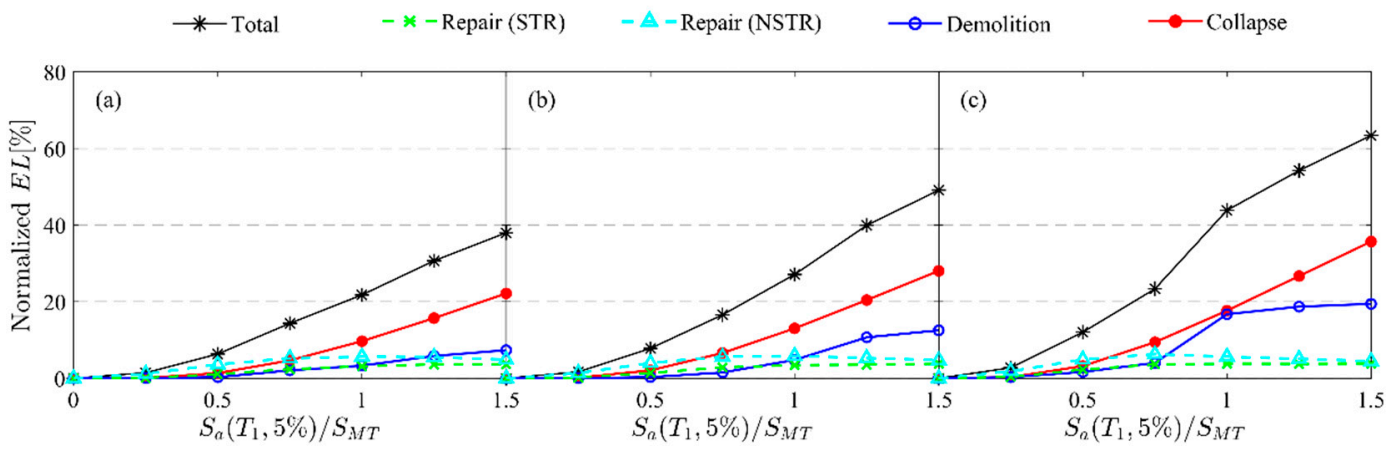

Figure 12. Normalized expected seismic loss of 15-story steel OMFs: (a) W0-OMF; (b) W44-OMF; (c) W51-OMF.

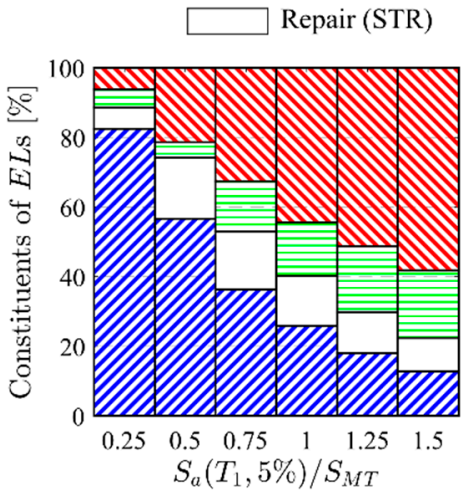

(a)

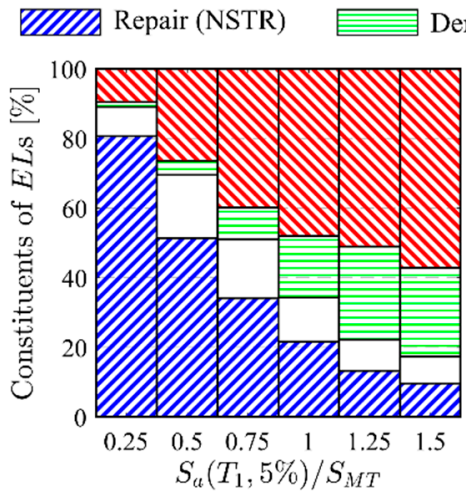

(b)

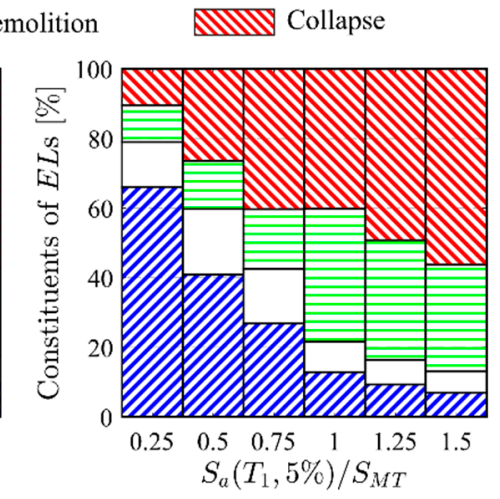

(c)

Figure 13. Composition ratio of repair, demolition, and collapse for $E L$ of 15 -story steel OMFs: (a) W0-OMF; (b) W44-OMF; (c) W51-OMF.

As shown in Figure 12, the $E L$ values of the W0-OMF for individual limit states are less than those of W44- and W51-OMFs irrespective of $i m$. The W51-OMF has larger EL values for individual limit states than W44-OMF. This indicates that the seismic loss could increase when wind loads are considered in the design. As mentioned earlier, the concentrations of lateral displacement in the upper stories for OMFs designed with consideration of wind loads cause a rapid increase in the maximum SDR in the upper stories, which not only 
accelerates the damage of structural and nonstructural components but also causes an increase in RIDR and an increase in the probability of sideway collapse. The $E L$ of the W44-OMF is at least 7\% larger than that of the W0-OMF. The probability of collapse and demolition limit states rapidly increases with an increase in $i m$. The $E L$ value increases up to $25 \%$. For the W51-OMF, the $E L$ value increases by at least $50 \%$ as compared twith that for the W0-OMF. The largest increase in the $E L$ value is $78 \%$.

Figure 13 shows the contribution (\%) of repair, demolition, and collapse to $E L$ as a function of $i m$. As seen in this figure, seismic loss associated with the repair limit state is dominant on $E L$ at low hazard levels. However, the contribution of seismic loss associated with demolition and collapse grows with an increase in im. As shown in Figure 6, OMFs experience significant damages in few stories and collapse. Therefore, the loss associated with demolition and collapse surpasses that associated with repair when im exceeds the MCE hazard level. For im corresponding to the MCE hazard level $\left(S_{M T}\right)$, seismic loss associated with demolition, and collapse limit states become more than $50 \%$ the total $E L$. The contribution (\%) of demolition and collapse on EL is the largest for the W51-OMF and is the least for the W0-OMF. This observation can be expected because OMFs designed with consideration of wind loads have higher seismic risk than corresponding OMFs designed without the consideration of wind loads as described in Section 4.

Figure 14 shows the expected annual loss (EAL) of W0-, W44-, and W51-OMFs. As in Figure 13, EAL normalized by replacement cost for repair, demolition, and collapse limit states are marked.
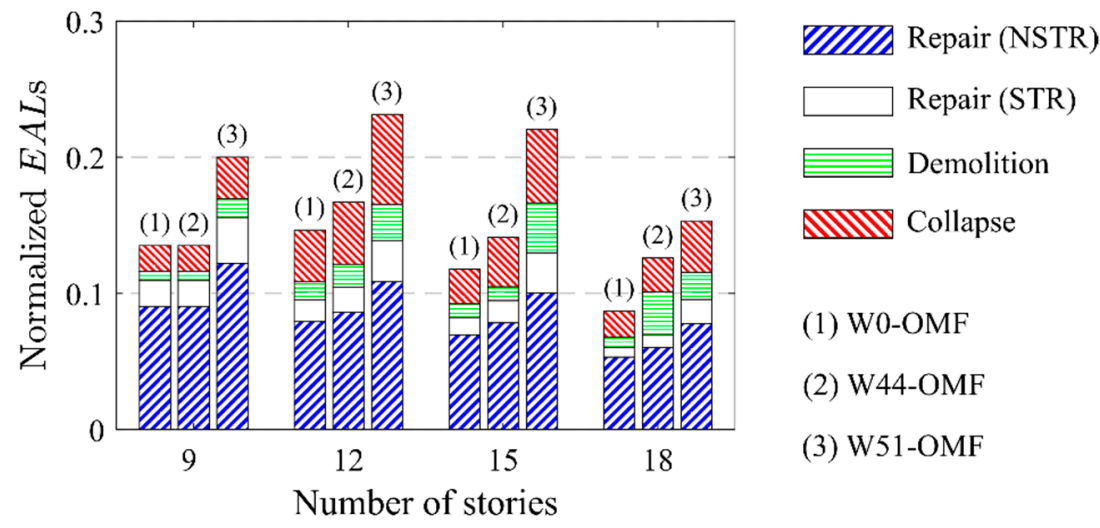

(1) W0-OMF

(2) $\mathrm{W} 44-\mathrm{OMF}$

(3) W51-OMF

Figure 14. Normalized expected annual losses of all model buildings.

As was observed in $E L$, the $E A L$ value also increases when wind loads are considered. The $E A L$ associated with repair also significantly increases for OMFs designed with consideration of wind loads. The $E A L$ value associated with repair is more than $50 \%$ of the total $E A L$. This is because of the frequency of ground motion with low intensity.

The total $E A L$ values of $12-, 15-$, and 18 -story W44-OMFs are $14 \%, 20 \%$, and $45 \%$ larger than those of corresponding W0-OMFs, respectively. An increase in $E A L$ is more significant for W51-OMF. The total EALs of 12-, 15-, and 18-story W51-OMFs are $48 \%, 58 \%, 87 \%$, and $76 \%$ larger than those of corresponding in 9-, 12-, 15-, and 18-story W0-OMFs, respectively. In this regard, if seismic performance evaluation is conducted for new buildings designed without consideration of wind loads, unconservative results can be obtained.

\section{Conclusions}

In this study, the seismic risk of steel ordinary moment frames (OMFs) designed with and without the consideration of wind loads were evaluated to investigate the effect of wind loads on the seismic performance of the steel OMFs. The seismic collapse intensities and seismic loss were estimated according to FEMA P695 and FEMA P58 methodologies, respectively. Nine-, twelve-, fifteen-, and eighteen-story steel OMFs were considered, and wind load of 0,44 , and $51 \mathrm{~m} / \mathrm{s}$ were used for the design of OMFs. The following conclusions are obtained from this study. 
1. OMFs designed with consideration of gravity, seismic, and wind loads (W44- and W51-OMF) have larger member sections than OMFs designed when only gravity and seismic loads (W0-OMF) are considered, particularly for interior columns and beams in the lower stories.

2. The period-based ductility $\left(\mu_{T}\right)$ of W44- and W51-OMFs was larger than that of corresponding W0-OMFs. However, values of overstrength factor $(\Omega)$ of W44- and W51-OMFs are similar with those of W0-OMFs. All steel OMFs had the $\Omega$ values smaller than 3.0, which is specified for steel OMFs in ASCE 7-16 [1]. This is because in OMFs, failure occurred in the upper stories before reaching the intended maximum base shear capacity expected in the design.

3. Due to the increase in member sections only in the lower stories for W44- and W51-OMFs, lateral drift and damage concentrated in the upper stories. Although W44- and W51-OMFs had larger member sections than corresponding W0-OMFs, those frames had higher collapse risk than corresponding W0-OMFs.

4. Seismic losses for W51- and W44-OMFs were larger than that for corresponding W0-OMFs at all hazard levels. Seismic losses associated with all limit states for W44and W51-OMFs were also larger than corresponding W0-OMFs, which was more apparent with an increase in building height and the magnitude of wind loads.

5. The EL values of the W0-OMF for individual limit states are less than those of W44and W51-OMFs irrespective of $\mathrm{im}$. W51-OMFs has larger $E L$ values for individual limit states than W44-OMFs. This indicates that the seismic loss could increase when wind loads are considered in the design. The EL of the W44-OMF is at least 7\% larger than that of the W0-OMF. For the W51-OMF, the EL value increases by at least $50 \%$ as compared with that for the W0-OMF. The largest increase in the $E L$ value is $78 \%$.

6. As was observed in $E L$, the $E A L$ value also increases when wind loads are considered. The total EAL values of $12-, 15-$, and 18-story W44-OMFs are $14 \%, 20 \%$, and $45 \%$ larger than those of corresponding W0-OMFs, respectively. An increase in EAL is more significant for W51-OMFs. The total EALs of 12-, 15-, and 18-story W51-OMFs are 48\%, $58 \%, 87 \%$, and $76 \%$ larger than those of corresponding W0-OMFs, respectively. In this regard, if seismic performance evaluation is conducted for new buildings designed without consideration of wind loads, unconservative results can be obtained.

7. Based on this study, it is important to consider the effect of wind loads when evaluating the seismic performance of steel structures. Otherwise, evaluation results could be unconservative.

Author Contributions: Conceptualization, S.W.H.; investigation, S.W.H.; methodology, T.K.; structural design, S.I.C. and T.K.; data curation, S.I.C.; analysis, T.K.; validation, S.W.H. and T.K.; visualization, T.K.; write-original draft preparation, T.K.; supervision, S.W.H.; revised and finalized the paper, S.W.H.; project administration, S.W.H. All authors have read and agreed to the published version of the manuscript.

Funding: This research received no external funding.

Institutional Review Board Statement: Not applicable.

Informed Consent Statement: Not applicable.

Data Availability Statement: Data are available from the corresponding author upon reasonable request.

Acknowledgments: This research was supported by grants from the National Research Foundation of Korea (NRF-2020R1A2C2010548).

Conflicts of Interest: The authors declare no conflict of interest. 


\section{Appendix A}

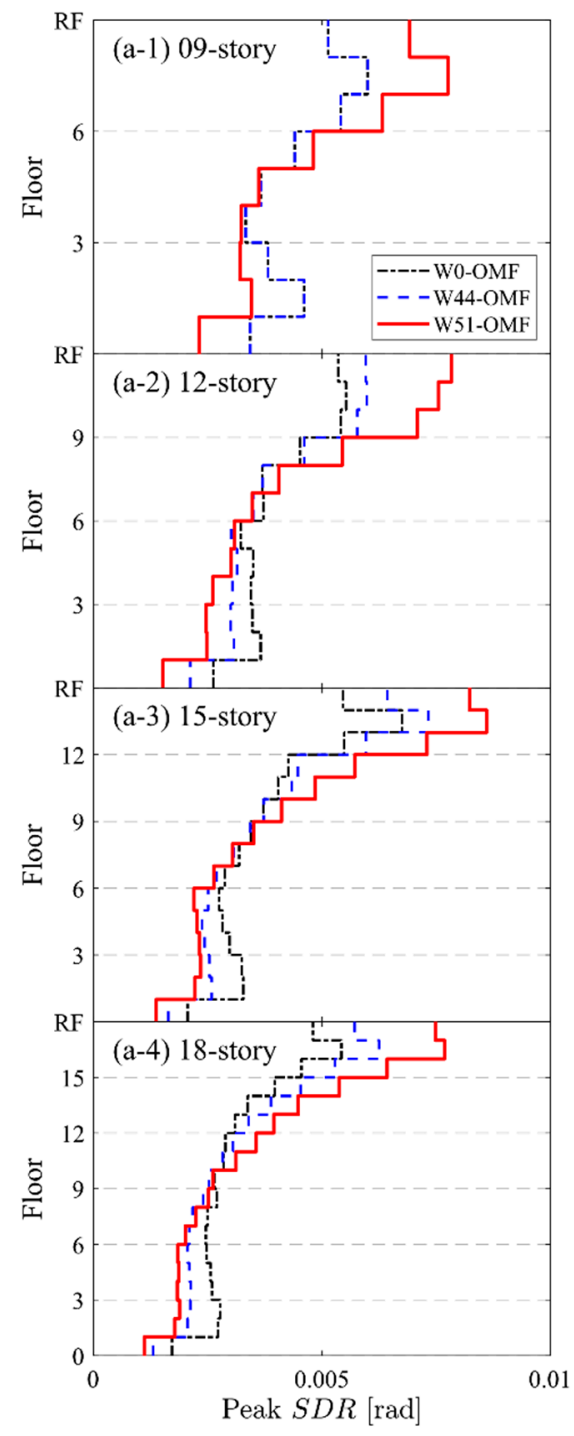

(a)

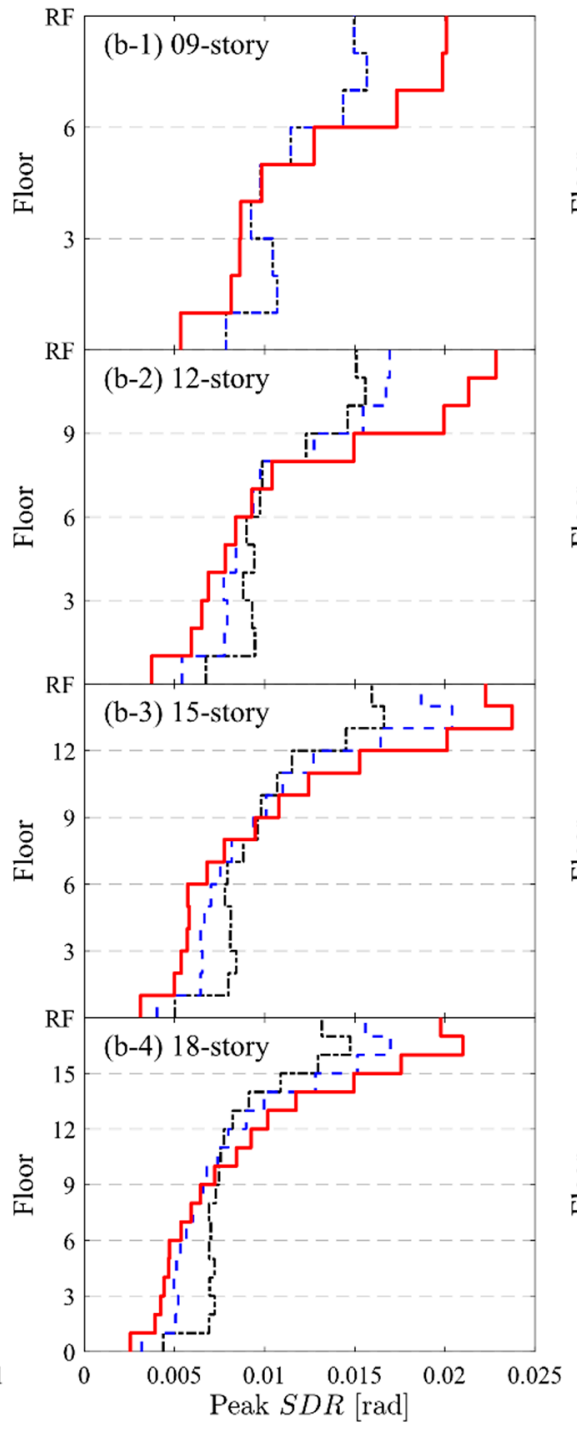

(b)

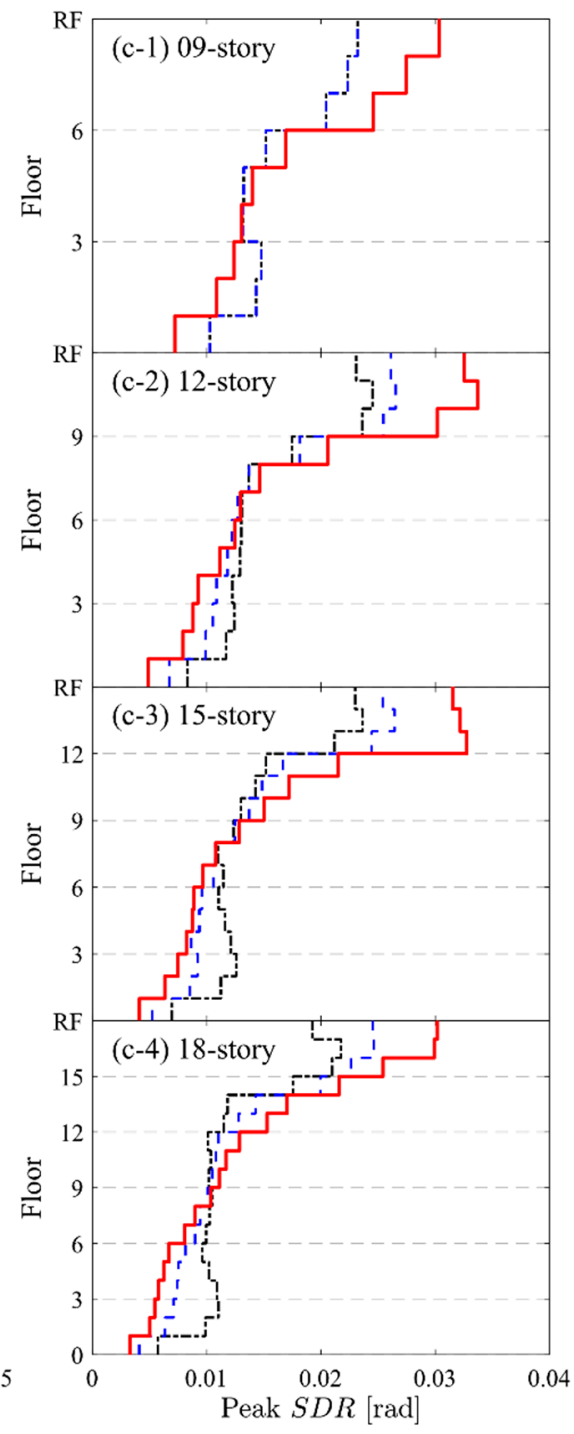

(c)

Figure A1. Peak story drift ratio $(S D R)$ for given specific intensity measure (im): (a) Service level earthquake (SLE); (b) design-based earthquake (DBE); (c) maximum considered earthquake (MCE).

\section{References}

1. American Society of Civil Engineers. Minimum Design Loads for Building and Other Structures; ASCE/SEI 7-16; American Society of Civil Engineers: Reston, VA, USA, 2017; ISBN 9780784479964.

2. American Institute of Steel Construction. Specification for Structural Steel Buildings; ANSIAISC 360-16; American Institute of Steel Construction: Chicago, IL, USA, 2016.

3. American Institute of Steel Construction. Seismic Provisions for Structural Steel Buildings; ANSI/ANSI 341-16; American Institute of Steel Construction: Chicago, IL, USA, 2016.

4. Prequalified Connections for Special and Intermediate Steel Moment Frames for Seismic Applications; ANSI/AISC 358-16; American Institute of Steel Construction: Chicago, IL, USA, 2016.

5. Han, S.W.; Kwon, O.-S.; Lee, L.-H. Evaluation of the seismic performance of a three-story ordinary moment-resisting concrete frame. Earthq. Eng. Struct. Dyn. 2004, 33, 669-685. [CrossRef]

6. Han, S.W.; Jee, N. Seismic behaviors of columns in ordinary and intermediate moment resisting concrete frames. Eng. Struct. 2005, 27, 951-962. [CrossRef]

7. Challa, V.R.M.; Hall, J.F. Earthquake collapse analysis of steel frames. Earthq. Eng. Struct. Dyn. 1994, 23, 1199-1218. [CrossRef]

8. Cornell, C.A.; Jalayer, F.; Hamburger, R.O.; Foutch, D.A. Probabilistic Basis for 2000 SAC Federal Emergency Management Agency Steel Moment Frame Guidelines. J. Struct. Eng. 2002, 128, 526-533. [CrossRef] 
9. Han, S.W.; Chopra, A.K. Approximate incremental dynamic analysis using the modal pushover analysis procedure. Earthq. Eng. Struct. Dyn. 2006, 35, 1853-1873. [CrossRef]

10. Harris, J.; Speicher, M. Assessment of Performance-Based Seismic Design Methods in ASCE 41 for New Steel Buildings: Special Moment Frames. Earthq. Spectra 2018, 34, 977-999. [CrossRef]

11. Lee, K.; Foutch, D.A. Performance evaluation of new steel frame buildings for seismic loads. Earthq. Eng. Struct. Dyn. 2001, 31, 653-670. [CrossRef]

12. National Institute of Standards and Technology. Evaluation of the FEMA P-695 Methodology for Quantification of Building Seismic Performance Factors; NIST GCR 10-917-8; NEHRP Consultants Joints Venture: Gaithersburg, MD, USA, 2012.

13. National Institute of Standards and Technology. Tentative Framework for Development of Advanced Seismic Design Criteria for New Buildings; NIST GCR 12-917-20; NEHRP Consultants Joints Venture: Gaithersburg, MD, USA, 2012.

14. Pirizadeh, M.; Shakib, H. On a Reliability-Based Method to Improve the Seismic Performance of Midrise Steel Moment Resisting Frame Setback Buildings. Int. J. Steel Struct. 2018, 19, 58-70. [CrossRef]

15. Roeder, C.W.; Schneider, S.P.; Carpenter, J.E. Seismic Behavior of Moment?Resisting Steel Frames: Analytical Study. J. Struct. Eng. 1993, 119, 1866-1884. [CrossRef]

16. Mai, C.; Konakli, K.; Sudret, B. Seismic fragility curves for structures using non-parametric representations. Front. Struct. Civ. Eng. 2017, 11, 169-186. [CrossRef]

17. Behnam, B.; Shojaei, F.; Ronagh, H.R. Seismic progressive-failure analysis of tall steel structures under beam-removal scenarios. Front. Struct. Civ. Eng. 2019, 13, 904-917. [CrossRef]

18. Moon, K.-H.; Han, S.W.; Lee, T.S.; Seok, S.W. Approximate MPA-based method for performing incremental dynamic analysis. Nonlinear Dyn. 2011, 67, 2865-2888. [CrossRef]

19. Lignos, D.G.; Krawinkler, H. Deterioration Modeling of Steel Components in Support of Collapse Prediction of Steel Moment Frames under Earthquake Loading. J. Struct. Eng. 2011, 137, 1291-1302. [CrossRef]

20. Abdollahzadeh, G.; Shabanian, S.M. Experimental and numerical analysis of beam to column joints in steel structures Front. Struct. Civ. Eng. 2018, 12, 642-661. [CrossRef]

21. Han, S.W.; Moon, K.H.; Ha, S.J. Seismic performance of high-rise intermediate steel moment frames according to rotation capacities of moment connections. Int. J. High-Rise Build. 2015, 4, 27-37. [CrossRef]

22. Kim, T.; Yu, E. Seismic performance of low-rise intermediate steel moment frame buildings in South Korea. Int. J. Steel Struct. 2017, 17, 1331-1340. [CrossRef]

23. Mashayekhi, A.H.; Gerami, M.; Siahpolo, N. Assessment of Higher Modes Effects on Steel Moment Resisting Structures under Near-Fault Earthquakes with Forward Directivity Effect Along Strike-Parallel and Strike-Normal Components. Int. J. Steel Struct. 2019, 19, 1543-1559. [CrossRef]

24. Chen, R.; Qiu, C.; Hao, D. Seismic Response Analysis of Multi-Story Steel Frames Using BRB and SCB Hybrid Bracing System. Appl. Sci. 2019, 10, 284. [CrossRef]

25. Montuori, R.; Nastri, E.; Piluso, V.; Todisco, P. Evaluation of the Seismic Capacity of Existing Moment Resisting Frames by a Simplified Approach: Examples and Numerical Application. Appl. Sci. 2021, 11, 2594. [CrossRef]

26. Kang, J.-D.; Mori, Y. Evaluation of a Simplified Method to Estimate the Peak Inter-Story Drift Ratio of Steel Frames with Hysteretic Dampers. Appl. Sci. 2017, 7, 449. [CrossRef]

27. Nikellis, A.; Sett, K.; Whittaker, A.S. Multihazard Design and Cost-Benefit Analysis of Buildings with Special Moment-Resisting Steel Frames. J. Struct. Eng. 2019, 145, 04019031. [CrossRef]

28. Venanzi, I.; LaVan, O.; Ierimonti, L.; Fabrizi, S. Multi-hazard loss analysis of tall buildings under wind and seismic loads. Struct. Infrastruct. Eng. 2018, 14, 1295-1311. [CrossRef]

29. Federal Emergency Management Agency. Quantification of Building Seismic Performance Factors; FEMA P-695; Federal Emergency Management Agency: Washington, DC, USA, 2009.

30. Federal Emergency Management Agency. Seismic Performance Assessment of Buildings_Vol. 1. Methodology; FEMA P-58; Federal Emergency Management Agency: Washington, DC, USA, 2018.

31. American Institute of Steel Construction. Steel Construction Manual, 4th ed.; American Institute of Steel Construction: Chicago, IL, USA, 2015.

32. CSI. ETABS software: Structural Analysis Program; Version 18.1.0; Computers and Structures, Inc.: Berkeley, CA, USA, 2019.

33. McKenna, F. OpenSees: A Framework for Earthquake Engineering Simulation. Comput. Sci. Eng. 2011, 13, 58-66. [CrossRef]

34. Applied Technology Council. Modeling and Acceptance Criteria for Seismic Design and Analysis of Tall Buildings; PEER/ATC 72-1; Applied Technology Council: Redwood City, CA, USA, 2010.

35. National Institute of Standards and Technology. Guidelines for Nonlinear Structural Analysis for Design of Buildings; NIST GCR 17-917-46v1; NEHRP Consultants Joints Venture: Gaithersburg, MD, USA, 2017.

36. Zareian, F.; Medina, R. A practical method for proper modeling of structural damping in inelastic plane structural systems. Comput. Struct. 2010, 88, 45-53. [CrossRef]

37. Lignos, D.G.; Hartloper, A.R.; Elkady, A.; Deierlein, G.G.; Hamburger, R. Proposed Updates to the ASCE 41 Nonlinear Modeling Parameters for Wide-Flange Steel Columns in Support of Performance-Based Seismic Engineering. J. Struct. Eng. 2019, 145, 04019083. [CrossRef] 
38. Gupta, A.; Krawinkler, H. Seismic Demands for Performance Evaluation of Steel Moment Resisting Frame Structures; Rep. No. 132; John A. Blume Earthquake Engineering Research Center: Stanford, CA, USA, 1999.

39. Ibarra, L.F.; Medina, R.A.; Krawinkler, H. Hysteretic models that incorporate strength and stiffness deterioration. Earthq. Eng. Struct. Dyn. 2005, 34, 1489-1511. [CrossRef]

40. American Society of Civil Engineers. Seismic Evaluation and Retrofit of Existing Buildings; ASCE/SEI 41-17; American Society of Civil Engineers: Washington, DC, USA, 2017.

41. Stojadinovic, B.; Goel, S.C.; Lee, K.-H.; Margarian, A.G.; Choi, J.-H. Parametric Tests on Unreinforced Steel Moment Connections. J. Struct. Eng. 2000, 126, 40-49. [CrossRef]

42. Han, S.W.; Kwon, G.U.; Moon, K.H. Cyclic behaviour of post-Northridge WUF-B connections. J. Constr. Steel Res. 2007, 63, 365-374. [CrossRef]

43. Han, S.W.; O Kim, T.; Baek, S.J. Seismic Performance Evaluation of Steel Ordinary Moment Frames. Earthq. Spectra 2018, 34, 55-76. [CrossRef]

44. Elkady, A.; Lignos, D.G. Effect of gravity framing on the overstrength and collapse capacity of steel frame buildings with perimeter special moment frames. Earthq. Eng. Struct. Dyn. 2014, 44, 1289-1307. [CrossRef]

45. Elkady, A.; Lignos, D.G. Modeling of the composite action in fully restrained beam-to-column connections: Implications in the seismic design and collapse capacity of steel special moment frames. Earthq. Eng. Struct. Dyn. 2014, 43, 1935-1954. [CrossRef]

46. Flores, F.X.; Charney, F.A.; Lopez-Garcia, D. Influence of the gravity framing system on the collapse performance of special steel moment frames. J. Constr. Steel Res. 2014, 101, 351-362. [CrossRef]

47. Vamvatsikos, D.; Cornell, C.A. Incremental dynamic analysis. Earthq. Eng. Struct. Dyn. 2001, 31, 491-514. [CrossRef]

48. Eads, L.; Miranda, E.; Krawinkler, H.; Lignos, D.G. An efficient method for estimating the collapse risk of structures in seismic regions. Earthq. Eng. Struct. Dyn. 2012, 42, 25-41. [CrossRef]

49. Federal Emergency Management Agency. Next-Generation Performance-Based Seismic Design Guidelines; FEMA 445; Federal Emergency Management Agency: Washington, DC, USA, 2006.

50. Ramirez, C.M.; Miranda, E. Significance of residual drifts in building earthquake loss estimation. Earthq. Eng. Struct. Dyn. 2012, 41, 1477-1493. [CrossRef]

51. Federal Emergency Management Agency. Supporting Electronic Materials and Background Documentation. In Seismic Performance Assessment of Buildings; FEMA P-58; Federal Emergency Management Agency: Washington, DC, USA, 2018 ; Volume 3.

52. Federal Emergency Management Agency. Expected Seismic Performance of Code-Conforming Buildings. In Seismic Performance Assessment of Buildings; FEMA P-58; Federal Emergency Management Agency: Washington, DC, USA, 2018 ; Volume 5. 